\title{
Investigation of the relationship between the strength limit and the long time fatigue of steel reinforcements of reinforced concrete structures
}

\author{
Denys Chernyshev ${ }^{1}$, Yulia Makarenko², Tetiana Khomutetska1, 3, Valeriy Makarenko1,4 \\ ${ }^{1}$ Kyiv national university of construction and architecture \\ Povitroflotskiy avenue 31, Kyiv, Ukraine, 03037 \\ tagm@ukr.net, orcid.org/0000-0002-1946-9242 \\ 2 University of Manitoba \\ 750 Bannatyne Avenue, Winnipeg, Canada \\ green555tree@gmail.com, orcid.org/0000-0003-1252-4231 \\ ${ }^{3}$ orcid.org/0000-0003-0153-4920, ${ }^{4}$ orcid.org/0000-0001-9178-9657
}

Received 11.09.2022, accepted for publication 25.09.2022
https://doi.org/10.32347/tit2021.42.0201

\begin{abstract}
The results of experimental studies have shown a strong effect of diffusion hydrogen on the static and cyclic parameters of crack resistance of reinforcing steel. It was found that with increasing flooding, especially when the hydrogen content exceeds $5 \mathrm{~cm}^{3} / 100 \mathrm{~g}$, both static strength and long-term strength (fatigue) decrease sharply. Moreover, these areas of hydrogen solution in reinforcing steel are characterized by a viscous nature of fracture, while for heavily flooded reinforcement (from 5 to $12 \mathrm{~cm}^{3} / 100 \mathrm{~g}$ ) is characterized by brittle fracture by the mechanism of microcracking in the hardened (martensite or troostite structure). The analysis of the obtained experimental results allowed to determine the optimal hydrogen content in the reinforcing steel $\left(3 \ldots 5 \mathrm{~cm}^{3} / 100 \mathrm{~g}\right)$, the excess of which can cause a decrease in the crack resistance of the reinforcement during long-term operation, especially in corrosive environments.

The mechanism of hydrogen influence on crack resistance of metal at static and alternating loading which consists in diffusion and dislocation movement of hydrogen in structure of a reinforcing core that as a result that causes strong flooding of steel and its embrittlement is offered. It is established that carbon and low-alloy sieves, which are characterized by ferritic-pearlitic and sorbitol structure provide high resistance, especially to long-term fatigue, and the transition to steels with a structure of martensite or tempered (transient structure of bainite) structure of bainite sharply reduces reinforcing steel, which makes it impossible to use in the manufacture of
\end{abstract}

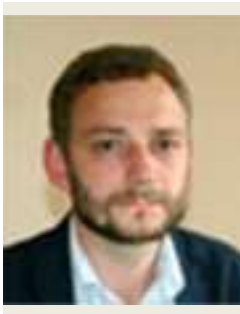

Denys Chernyshev

Vece-rector

Dr.Tech.Sc., Prof.

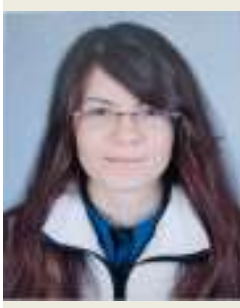

Yulia Makarenko

Department of Biochemistry

Bachelor

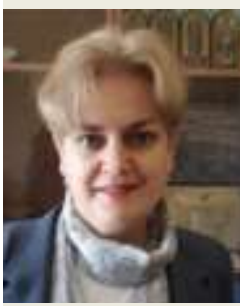

Tetiana Khomutetska

Professor of the Department

of Water Supply and Sewerage

Dr.Tech.Sc., Prof.

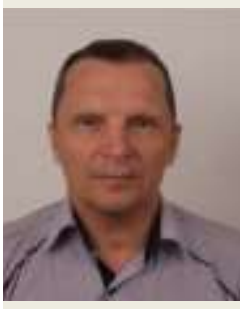

Valeriy Makarenko

Professor of the Department

of Water Supply and Sewerage

Dr.Tech.Sc., Prof.

reinforcement involved in reinforced concrete structures designed for long-term operation (more than $50 \ldots 60$ years). Thus, the obtained diagram 
can be recommended to designers of reinforced concrete structures for hydraulic purposes, as it greatly facilitates the reasonable choice of reinforcement in the development of reinforced concrete structures for responsible and long-term use.

Keywords: crack resistance, flooding, fatigue, cyclicity, fittings.

Introduction. It is known that the fatigue process begins with the plastic deformation of the surface layers of the metal fittings. Moreover, the displacement of dislocations under conditions of re-alternating loads is observed at loads below the elastic limit of the metal. The rate of local plastic deformation during cyclic deformation is several orders of magnitude higher than the rate of deformation under static loading. Dislocation slip begins in grains with a favorable orientation near stress concentrators. As the number of cycles in the surface layers increases, the density of dislocations and the number of vacancies increases. When the base number of $\mathrm{N}_{R}$ cycles is reached, a surface reinforced layer Af metal with a large number of germinal cracks is formed, the size of which does not reach a critical value. Increasing the number of cycles cannot cause further development of fracture in such a layer. Only when the stresses exceed the endurance limit of the crack reach a critical length, after which the process of their discharge into the main crack begins with the spread of the latter. The results of experimental studies indicate a strong effect of diffusion hydrogen on static and cyclic parameters of crack resistance. It was found that with increasing flooding, especially when the hydrogen content exceeds $5 \mathrm{~cm}^{3} / 100 \mathrm{~g}$, both static strength and long-term strength (fatigue) decrease sharply. Moreover, for these areas of hydrogen solution in reinforcing steel is characterized by a viscous nature of fracture, while for heavily flooded reinforcement (from 5 to $12 \mathrm{~cm}^{3} / 100 \mathrm{~g}$ is characterized by brittle fracture by the mechanism of microfission in the hardened (martensite or troostite structure). Allowed to determine the optimal hydrogen content in reinforcing steel $\left(3 \ldots 5 \mathrm{~cm}^{3} / 100 \mathrm{~g}\right)$, the excess ofwhich will reduce the crack resistance of reinforcement during long-term operation, especially in corrosive environments. The results of the research confirm the above data. bainite structure $y$ sharply reduces the crack resistance of reinforcing steel, which makes it impossible to use in the manufacture of reinforcement involved in reinforced concrete structures designed for long-term operation (more than $50 \ldots 60$ years). Thus, the obtained diagram can be recommended to designers of reinforced concrete structures for hydraulic purposes, as it greatly facilitates the reasonable choice of reinforcement in the development of reinforced concrete structures for responsible and long-term use.

It is known [1 - 5] that the resistance of the metal to fatigue failure is characterized by the limit of endurance (fatigue), ie it is the highest stress that can withstand the metal without failure at any number of cycles. The limit of endurance is most often determined in tests with alternating symmetrical cycle $(\mathrm{R}=-1)$, and therefore the endurance limit is denoted by $\sigma_{-1}$.

As a rule, the endurance limit is limited to $10^{7}$ cycles (this number of cycles is called the test base). Thus, it can be noted that the endurance limit is the maximum cycle stress that can withstand the material without destruction at the base number of cycles (for ferrous metals, this base is $10^{7}$ cycles). Then on fatigue curves it is possible to find such important indicator, as durability at fatigue under which accept number of cycles of loading which maintains steel at destruction at a certain pressure.

It is known from the literature [1] that the endurance limit in metal correlates well with the mechanical properties of metals. Thus, the value of $\sigma_{-1}$ is on average $(0.4 \ldots 0.6) \sigma_{B}-$ for carbon and alloy steels; $(0.3 \ldots 0.5) \sigma_{B}-$ for bronze and brass. This characteristic can be similarly compared with Brinell hardness: $\sigma_{-1}=(0.128 \ldots 0.156) \mathrm{HB}$ - for carbon steels; $(0.168 \ldots 0.222) \mathrm{HB}$ - for alloy steels; $\sigma_{-1}=0.19 \mathrm{HB}-$ for aluminum alloys.

It is known from modern fracture mechanics [2..4] that with increasing number of cycles at any stresses above the endurance 
limit in metal, the following processes occur sequentially:

1) plastic deformation;

2) the formation of cracks, the cells of which are non-metallic inclusions (HB);

3) gradual development of some of them with the predominant spread of the main crack;

4) rapid final destruction.

The process of fatigue begins with the plastic deformation of the surface layers of the metal fittings. Moreover, the displacement of dislocations under conditions of re-alternating loads is observed at loads below the elastic limit of the metal. The rate of local plastic deformation during cyclic deformation is several orders of magnitude higher than the rate of deformation under static loading. Dislocation slip begins in grains with a favorable orientation near stress concentrators. As the number of cycles in the surface layers increases, the density of dislocations and the number of vacancies increases. When the base number of $\mathrm{N}_{R}$ cycles is reached, a surface reinforced layer of metal with a large number of germinal cracks is formed, the size of which does not reach a critical value. Increasing the number of cycles cannot cause further development of fracture in such a layer. Only when the stresses exceed the endurance limit of the crack reach a critical length, after which the process of their discharge into the main crack begins with the spread of the latter.

Formulation of problems and relevance of the topic. The ultimate stresses at which the process begins, for example, hydrogen sulfide fracture (HSF), are recommended as criteria for comparing the stability of different reinforcing steels $[5,6]$. One of the important factors influencing the resistance to HSF is the composition and structure of steel. Yes, carbon has a significant effect on HSF. It is known $[6,7]$ that with increasing amount of carbon the tendency of hardened steels to HSF increases due to increasing internal stresses. Hydrogen diffusing into the metal, even in small quantities $\left(2 \ldots 3 \mathrm{~cm}^{3} / 100 \mathrm{~g}\right)$ does not cause sufficient for the development of cracks of local plastic deformations in strong metal. It is believed that steel loses its visco-plastic characteristics at a hydrogen content in the range of $7 \ldots 12 \mathrm{~cm}^{3} / 100 \mathrm{~g}$ [8]. However, as established in [9], hydrogen fragility can occur with a small amount of absorption (absorbed) hydrogen. Thus, in steel with a tensile strength of $1600 \mathrm{MPa}$, doped with $0.7 \% \mathrm{Cu}$, $0.25 \% \mathrm{Mo}, \quad 0.8 \% \mathrm{Nb}$ and $0.025 \% \mathrm{Al}, \mathrm{a}$ decrease in plastic properties $(\delta)$ was observed from 45 to $3 \%$ at the level of flooding $0.03 \mathrm{~cm}^{3} / 100 \mathrm{~g}$.

In our opinion, this phenomenon can be explained with the involvement of the sorption-electrochemical mechanism of longterm strength (fatigue) [10].

Static (hydrogen) fatigue is caused by sorption processes:

1) diffusion of hydrogen into the defects of the crystal lattice of the metal;

2) adsorption of hydrogen by the inner surfaces of the crystal structure;

3 ) the pressure of moly hydrogen in the reservoirs;

4) weakening of the bonding forces between atoms in the crystal lattice of the metal.

That is, even with sufficient viscosity and ductility of the metal (for example, low-alloy steel $-08 Г 2 \mathrm{C}, 15 \mathrm{XCHД),} \mathrm{due} \mathrm{to} \mathrm{the}$ adsorption of hydrogen in microdefects (microcapillaries, pores), the formation of microcracks is facilitated due to low resistance of brittle material.

Analysis of the literature shows that according to modern physical and mechanical ideas about the nature of static fatigue of the metal there is a critical concentration of hydrogen, which sharply weakens the cohesive bonds in the crystal lattice, ie the rupture of interatomic bonds. According to the developed diffusion model of hydrogen segregation, the critical value of hydrogen depends on the grade of steels, stress state, operating conditions. In our case (underground sewer system) the critical level of hydrogen in the fittings is approximately $5 \ldots 6 \mathrm{~cm}^{3} / 100 \mathrm{~g}$ [11]. This volume is sufficient to dramatically accelerate the process of nucleation and development of cracks (submicrocracks). Therefore, appropriate measures are required 
to influence the dislocation mechanism of hydrogen delivery into the valve structure.

It is established [5..7] that the distance between the sliding strips of dislocations is $\left(10^{-6} \ldots 10^{-4}\right) \mathrm{cm}$; the amount of slip is $\left(10^{-7} \ldots 10^{-5}\right) \mathrm{cm}$. The critical tangential stress is $\tau=\left(10^{-5} \ldots 10^{-7}\right) \mu$, where $\mu$ is the shear modulus equal to $(1 \ldots 11) 10^{4} \mathrm{MPa}$. Normal stress (perpendicular to the sliding plane) $\sigma=\left(10^{-5} \ldots 10^{-7}\right) \mu$. Theoretical lattice strength (shear strength in a perfect crystal) is taken as $\sigma_{\mathrm{T}}=\mu / 30$. It is assumed that the dislocations can be concentrated in some places, forming a cellular structure (subgrain). The size of subgrains (blocks) is equal $\left(10^{-7} \ldots 10^{-5}\right) \mathrm{cm}$.

In the calculations, the stress required to break the adhesion forces in the metal is taken equal to $85 \mathrm{MPa}$. It should be taken into account that in the structure of reinforcing steels the diffusion of hydrogen is facilitated by the presence of microdefects, dislocations, temperature-pressure gradient and variable loads (force factor).

It was found that the predominant amount of diffusion hydrogen is concentrated in traps, and the binding energy of atoms with them is approximately $\mathrm{HB} \approx 58.6 \mathrm{~kJ} / \mathrm{mol}$ [3]. At the same time, its concentration in the crystal lattice matrix decreases to $10^{2} \ldots 10^{3} \mathrm{~cm}^{-3}$, and in $\mathrm{N}_{\mathrm{B}(\mathrm{P})}$ traps. Under such conditions, at temperatures below $300 \ldots 320 \mathrm{~K}$, almost all hydrogen is captured by dislocations and traps, and the concentration in the lattice matrix is almost zero.

As noted above (according to the text), the critical concentration of hydrogen depends on the stresses in the steel and is largely determined by the structural composition. Therefore, to determine the delayed destruction by the mechanism of hydrogen embrittlement, causing static (hydrogen) fatigue, a binary combination of critical values of hydrogen concentration and mechanical stresses is required. The critical concentration of hydrogen is created under the influence of the three-dimensional space of the tensile stress field of the directed (collective) diffusion of hydrogen. The period during which the critical value is reached $\left(\mathrm{C}_{\mathrm{cr}}+\sigma_{\mathrm{cr}}\right)$ corresponds to the incubation period of microcracking growth. There are different views on the mechanism of nucleation and propagation of cracks caused by hydrogen embrittlement, but the hypothesis of molecular pressure of hydrogen is the most noteworthy, ie the main cause of high pressure hydrogen in non-continuous metal reinforcement, which causes high internal stresses. Moreover, on a microscale, the action of hydrogen can be manifested not so much in embrittlement as in the plasticization of the metal.

On a macro-scale, embrittlement looks like a reduction in the fracture stress due to local plastic flow and the destruction of metal microvolumes at the crack tip.

The mechanism of hydrogen-initiated nucleation of the microcrack and its subsequent growth involves a series of the following frequent processes:

- discharge of hydrogen ions on the surface of the body (blocks, dislocation traps, nonmetallic inclusions, phases of introduction, etc.) as a result of the cathodic reaction [10]:

$2 \mathrm{H}^{+}+\mathrm{e}^{-} \rightarrow[2 \mathrm{H}]$

$$
\downarrow
$$

where $[\mathrm{H}]_{\mathrm{Me}}-$ the concentration of dissolved atomic hydrogen in the metal, $\left(\mathrm{H}_{2}\right)$ - its concentration in the gas phase;

- penetration and transportation (by diffusion or dislocation mechanism) of hydrogen atoms in the region with high stress concentration, ie to the vertices of microcracking;

- ensuring the growth of microcracks as a result of hydrogen-induced decrease in the ductility of the flooded metal.

In [5], it was proved that hydrogen on atomically pure surfaces of submicrocracks forms a layer of anions resulting in a change in the energy state of the surface and hence the behavior of submicrocracks in the stress field. hydrogen on the movement of dislocations This peculiarity of the dislocation mechanism of hydrogen transport is due to the abnormally high coefficient of its diffusion and relatively low binding energy with dislocations.

It is known from the literature that microcracks form atomically pure surfaces on 
which hydrogen released from dislocations is chemisorbed. Thermodynamic calculations using the Gibbs equation show [2, 4] that hydrogen adsorption sharply reduces surface energy, especially at low concentrations on the surface $6.0 \ldots 7.5 \mathrm{~J} / \mathrm{cm}^{2}$ [9]). If you take into account the actual energy consumption for the destruction of iron $\left(\approx 10 \ldots 20 \mathrm{~J} / \mathrm{cm}^{2}\right)$, such a change will be very sensitive.

In addition, the formation of microcracks on the outskirts of collisions of dislocations is facilitated by stresses which at a distance of 1 $\mu \mathrm{m}$ from the core of the dislocation are equal (for helical dislocation according to Hooke's law) [3]:

$$
\begin{gathered}
\tau_{\chi \Theta}=\left(\mathrm{G}_{\mathrm{Fe}}+\mathrm{b}\right) /(2 \pi \mathrm{r})= \\
=\left(0.8 \cdot 10^{12}+2.510^{-8}\right) /\left(2 \pi \cdot 10^{-4}\right)= \\
=0.3210^{8} \mathrm{dyn} / \mathrm{cm}^{2}=32 \mathrm{~N} / \mathrm{mm}^{2} .
\end{gathered}
$$

Here $\mathrm{G}_{\mathrm{Fe}}=0.8 \cdot 10^{12} \mathrm{dyn} / \mathrm{cm}^{2}-$ modulus of elasticity of iron; $b=2.5 \cdot 10^{-8} \mathrm{~cm}-$ Burger's vector; $\mathrm{r}=1 \mu \mathrm{m}=10^{-4} \mathrm{~cm}-$ distance to the core of the dislocation; $\Theta \mathrm{i} \chi$-coordinates of a cylindrical system in which the $\chi$ axis is directed along the line of dislocation. According to the formula, the stresses decrease inversely proportional to the distance from the dislocation nucleus.

Dimension $b / 2 \pi=y_{\theta \chi}-$ relative shift.

The total theurgy of the elastic deformation of the helical dislocation per unit of its length is equal to:

$$
\begin{gathered}
\left.\mathrm{V}_{\text {helical }}=\left(\mathrm{G} \cdot \mathrm{b}^{2}\right) / 4 \pi\right) \cdot \ln \mathrm{R} / \mathrm{V}_{\mathrm{O}}= \\
=0.5 \cdot 10^{12}\left(3 \cdot 10^{-8}\right)^{2} / 4 \pi \cdot \ln \left(1 /\left(5 \cdot 10^{-8}\right)\right)= \\
=6 \cdot 10^{-4} \mathrm{erg} / \mathrm{cm}^{2} \cdot \mathrm{erg} / \text { interatomic distance }= \\
=12.5 \cdot 10^{7} \mathrm{eV} / \text { interatomic distance. }
\end{gathered}
$$

This is a very large energy, and therefore it contributes to the formation of microcracks in the presence of a catalyst - hydrogen. Let's calculate the effective mass of dislocations, attributed to a unit of its length (for helical dislocation):

$$
\begin{gathered}
\mathrm{m}_{\mathrm{e \phi}}=\mathrm{b}^{2} \cdot \gamma / 2= \\
=\left\{\left(2.5 \cdot 10^{-8}\right)^{2} \cdot 7.85\right\} / 2=2.45 \cdot 10^{-15} \mathrm{~g} / \mathrm{cm},
\end{gathered}
$$

where $\gamma=7.85 \mathrm{~g} / \mathrm{cm}^{3}-$ metal density.
As in $1 \mathrm{~cm}$ of length of dislocation keeps within $5 \cdot 10^{-8}-$ interatomic distances, $\mathrm{a}=2.5 \check{\mathrm{A}}$ $($ angstrom $\left.)=2.5 \cdot 10^{-8} \mathrm{~cm}\right)$,

$$
\begin{aligned}
& \text { Then } \mathrm{m}_{\mathrm{ef}}=\left(2.45 \cdot 10^{-15}\right) /\left(1 / 1.25 \cdot 10^{-8}\right)= \\
& =6.1 \cdot 10^{-23}(\mathrm{~g} / \text { interatomic distance }) \\
& \text { The mass of } 1 \mathrm{Fe} \text { atom is equal } \\
& \mathrm{m}=\mathrm{M} /\left(6.02 \cdot 10^{23}\right)=56 /\left(6.02 \cdot 10^{23}\right)= \\
& =9.3 \cdot 10^{-23} \mathrm{~g},
\end{aligned}
$$

where $\mathrm{M}$ is the atomic weight equal to $1 \mathrm{~g}$ atom.

Therefore, the effective mass of the dislocation at one interatomic distance is approximately equal to the mass of one atom. This indicates that the work of crack formation and growth due to high stresses and dislocation mobility is reduced in the presence of hydrogen adsorbed on the crack surface.

Rapid diffusion and propagation of cracks requires rapid diffusion of hydrogen atoms, if we take the rate of propagation of cracks $\mathrm{V}_{\text {r.tr }}=$ $=10^{-2} \mathrm{~cm} / \mathrm{s}$, which is proportional to the velocities of dislocations in ferritic-pearlitic steels, which include reinforced concrete reinforcement, and the coefficient of diffusion hydrogen, for example in $\alpha-\mathrm{Fe} \mathrm{D}_{\mathrm{H}} \approx 10^{-4}$ $\mathrm{cm}^{2} / \mathrm{c}$, and as a criterion for estimating the propagation of the microcrack parameter $\mathrm{X}^{-2}=$ $2 D_{H} \cdot t$, where $t$ is time, it follows that for a certain period of time $t$ at $V_{\text {p.tr }}=10^{-2} \mathrm{~cm} / \mathrm{s}$ mobility of hydrogen atoms is sufficient, even when $\mathrm{D}_{\mathrm{H}} \approx 10^{-6} \mathrm{~cm}^{2} / \mathrm{s}$.

The process of formation of fatigue cracks takes only $5 \ldots 10 \%$ of the operation time of structures until the final destruction. The rest of the term falls on the origin and gradual growth of cracks, most of which eventually slow down or completely suspend their development (due to the strengthening of the metal in places of concentrated stresses near the top of the crack). Only those cracks which have rather big length and sharp top receive the further development. One of them can lead to the final destruction of the reinforced concrete structure.

It should be noted that the reduction in the amount of cement in the steels of reinforcing bars with a service life is according to X-ray diffraction analysis of about $30 \ldots 35 \%$ and 
electron microscopic data - about $20 \ldots 25 \%$. It should be borne in mind that cementite is easily decomposed under the action of hydrogen atoms:

$$
\begin{gathered}
\mathrm{Fe}_{3} \mathrm{C} \leftrightarrow 3 \mathrm{Fe}+\mathrm{C}(24.3 \pm 2.01), \mathrm{kJ} \\
\mathrm{C}+2 \mathrm{H}_{2} \leftrightarrow \mathrm{CH}_{4}+(75.42 \pm 0.84), \mathrm{kJ}
\end{gathered}
$$

In general, this process is described by the reaction

$$
\mathrm{Fe}_{3} \mathrm{C}+2 \mathrm{H}_{2} \leftrightarrow 3 \mathrm{Fe}+\mathrm{CH}_{4}
$$

Atomic hydrogen easily appears at interaction of hydrogen sulfide which is contained even in insignificant amount of the stored technological environment (for example, sewage waters, with metal of reinforced concrete reinforcement):

$$
4 \mathrm{Fe}+6 \mathrm{H}_{2} \mathrm{~S}=2 \mathrm{Fe}_{2} \mathrm{~S}_{3}+12 \mathrm{H} .
$$

In the process of deformation on the surface of the armature metal or the surface of the microcavity, active centers are formed, in which the dissociation of hydrogen molecules and the penetration of atomic hydrogen into the depth of the armature metal takes place.

Decarburization of reinforcing steels takes place over a long period of time, which is facilitated by the temperature-pressure mode of transport of sewage in underground systems. Since under such conditions the mobility of carbon atoms in ferrite is low, the main hydrogen reaction takes place in the pearlitic grain. The diffusion coefficients of carbon and hydrogen in $\alpha-\mathrm{Fe}$ are as follows (temperature $\left.20^{\circ} \mathrm{C}\right)$ :

$$
\text { - for hydrogen }-15 \cdot 10^{-5} \mathrm{~cm}^{2} / \mathrm{s} \text {; }
$$$$
\text { - for carbon }-2 \cdot 10^{-17} \mathrm{~cm}^{2} / \mathrm{s} \text {. }
$$

The accumulation of the reaction products (methane and atomic hydrogen, which recombines into molecules) takes place initially in the pores and microcavities, in the boundary volumes of the grains of the armature metal. Atoms of impurities and cavities are concentrated along the grain boundaries, which promotes the creation of segregation, especially sulfur, as a result of which the boundary regions of the grains are also enriched with car- bon. In addition, the grain boundaries are energetically metastable.

The pressure of moly hydrogen in such can reach large values, resulting in stresses exceeding the cohesive strength of reinforcing steel of reinforced concrete structures, which often leads to the formation of microcracks in the metal, and in general to the degradation of reinforcing steels.

It should be noted that the analysis of literature sources of domestic and foreign researchers does not provide an unambiguous answer to the question of the influence of hydrogen and alternating stresses on the embrittlement of reinforcing steel of different brands, and the results of experimental studies are usually obtained in different conditions different external factors, and therefore characterized by contradictions, making them difficult to compare and draw final conclusions, although the problem of degradation of reinforced concrete structures is relevant and, moreover, is important for the construction industry of Ukraine, resulting in additional experimental and theoretical studies.

The goal of the work - study of hydrogen crack resistance of reinforcing rods of reinforced concrete structures of long service life in aggressive environments.

Methods of experimental research, materials, criteria and equipment. The object of research was reinforcing steel of the following grades: 5; 35ГC; 20ГС; 08Г2C; $15 \mathrm{XСНД;} \mathrm{Х18H9,} \mathrm{ie} \mathrm{steel} \mathrm{carbon,} \mathrm{low-alloy,}$ which had a structure of ferritic-perlite, sorbitol and troostite and martensitic with a coefficient of endurance $\mathrm{K}_{\mathrm{V}}=0.40 \ldots 0.50$. The effect of hydrogen on the endurance limit and static strength limit was investigated on samples of steel grade $20 \Gamma \mathrm{C}$ which before experiments were flooded to the required level in special chambers with hydrogen medium. The hydrogen content in steel samples cut from reinforcing bars was determined by vacuum melting on a chromatographic unit VH-6 company Gereus (Germany) [10, 11]. The duration of flooding of the samples was 
about $72 \ldots 78$ hours, depending on the required volume of flooding.

Samples of cylindrical shape with a length of $162 \mathrm{~mm}$, of which the working part was 50 $\mathrm{mm}$, and the diameter of the capture $-70 \mathrm{~mm}$ of the working part $-10 \mathrm{~mm}$, which allowed the fittings with a diameter of $32 \mathrm{~mm}$ (Fig. 1).

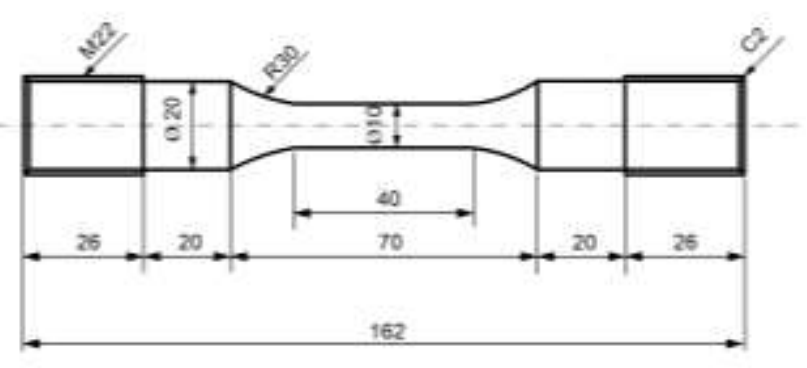

Fig. 1. Samples for fatigue strength tests (multi-cycle tests)

The samples perceived the deformation of the bend with axial compression-tension. The baseline test for prolonged fatigue was $\mathrm{N}=10^{7}$ cycles.

After fabrication, the reinforcement samples were subjected to different heat treatment modes depending on the steel grade and obtaining the desired type of structure. The samples were polished with a grinding skin with a grain size of $3 / 0$, and then subjected to tempering in a vacuum chamber at $620^{\circ} \mathrm{C}$ for $30 \mathrm{~min}$ to remove residual stresses. The samples were tested on the setpoint of the model "Instron" (UK). The tests were performed on a bend with zero average voltage and a cycle frequency of $20 \mathrm{~Hz}$. The tests were performed in air. The impact of the aggressive environment was absent. We add that the tests were performed in accordance with the requirements of the Specification of the International Association of Corrosive (Specification TenquizOil and Gas Plant // ProzessPlant.-Lurgi code: 65102-00-MALTENGUIZ II. Specification №.SPC-62900XP-007). Fractographic and metallographic studies were performed using an electron scanning microscope model Jeol-35SF (Japan). A fragment of the reinforcing rods, from which the samples for flooding were cut, followed by a test for long-term strength and factual studies, is shown in Fig. 2.

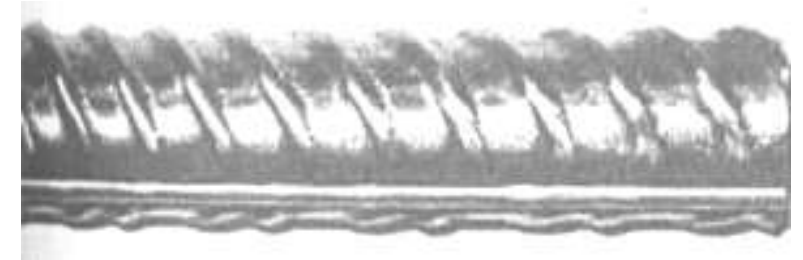

Fig. 2. Fragment of experimental reinforcement of reinforced concrete structure

Research results and their discussion. The results of experimental studies are shown in Fig. 1 and 2. The data in Fig. 1 indicate a strong effect of diffusion hydrogen on static and cyclic parameters of crack resistance. It can be seen (see Fig. 1) that with increasing flooding, especially when the hydrogen content exceeds $5 \mathrm{~cm}^{3} / 100 \mathrm{~g}$, both static strength and long-term strength (fatigue) decrease sharply. Moreover, these areas of hydrogen solution in reinforcing steel are characterized by a viscous nature of fracture, while for heavily flooded reinforcement (from 5 to $12 \mathrm{~cm}^{3} / 100 \mathrm{~g}$ is characterized by brittle fracture by the mechanism of microfission in the hardened (martensite or troostite structure). experimental results allowed to determine the optimal hydrogen content in reinforcing steel $\left(3 . .5 \mathrm{~cm}^{3} / 100 \mathrm{~g}\right)$, the excess of which will reduce the fracture toughness of reinforcement during long-term operation, especially in corrosive environments. (according to the text).

The results of the research presented in Fig. 3 confirm the data of Fig. 4. It can be seen from Fig. 4 that carbon and low-alloy sieves, which are characterized by ferritic-pearlitic and sorbitol structure provides high resistance primarily to prolonged fatigue, and the transition to steels with a structure of martensite or tempered (bainite transition jet) sharply reduces bainite structure. crack resistance of reinforcing steel, which makes it impossible to use in the manufacture of reinforcement involved in reinforced concrete structures designed for long-term operation (more than 50...60 years). Thus, the obtained diagram can be recommended to designers of reinforced concrete structures for hydraulic purposes, as it greatly facilitates the reasonable choice of reinforcement in the development of 
reinforced concrete structures for responsible and long-term use.

Steels with a tempering sorbitol structure have the highest survivability. This is due to the low growth rate of the fatigue crack due to the high ductility of the metal (see Fig. 4) and the presence of a developed substructure of the ferritic phase of sorbitol. The dislocation walls that separate the ferrite grains serve as barriers to the fatigue crack, which causes it to change direction in a zigzag pattern and spend more energy and time growing to a critical size. In addition, steel after heat treatment for tempering sorbitol becomes insensitive to the appearance of stress concentrators and accidental shock load.

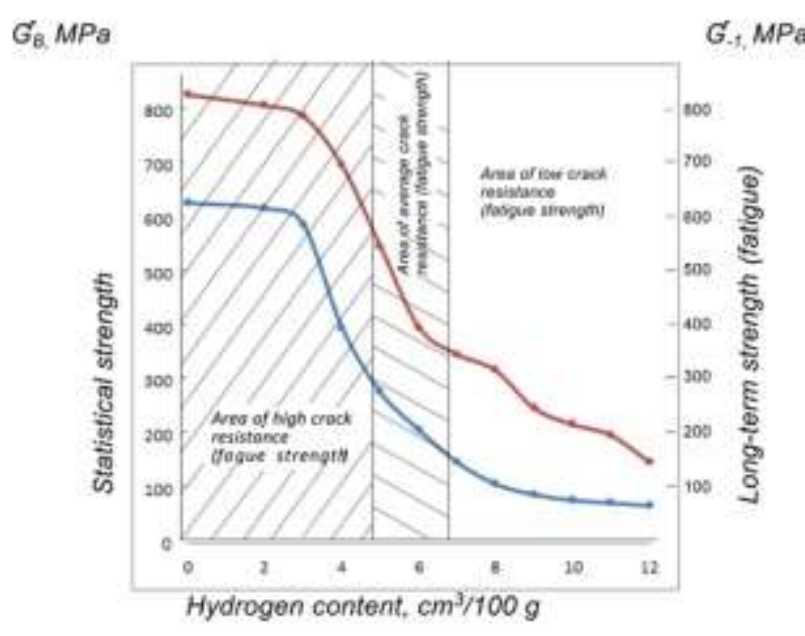

Fig. 3. Graphs of dependence of fatigue strength $\left(\sigma_{-1}\right)$ and static strength $\left(\sigma_{\mathrm{B}}\right)$ on the hydrogen content in the reinforcement samples. Reinforcing steel grade $20 \Gamma \mathrm{C}$. Test base $\mathrm{N}=10^{7}$ cycles. Designation: the red line refers to the static axis strength and the blue line refers to the axis of fatigue strength $\left(\sigma_{-1}\right)$

Steel heat-treated on cane or tempering martensite has a higher $\sigma_{-1}$, but its significant resistance to the formation of fatigue cracks is neutralized by increased sensitivity to surface quality. In addition, high-strength steels are characterized by low resistance to cracking.

Thus, the operating conditions require a special combination of high resistance to the formation of fatigue cracks and high resistance to its propagation, which is almost impossible to provide in reinforcing steel using alloying and heat treatment. This problem is solved by Transfer of Innovative Technologies Vol.4, No.2 (2021), 28-40 the use of surface hardening technologies (surface plastic deformation, chemical-thermal treatment, surface hardening) for low- or medium-carbon steels treated with the structure of tempering sorbets. The result is steels with a strong surface and a viscous plastic core.

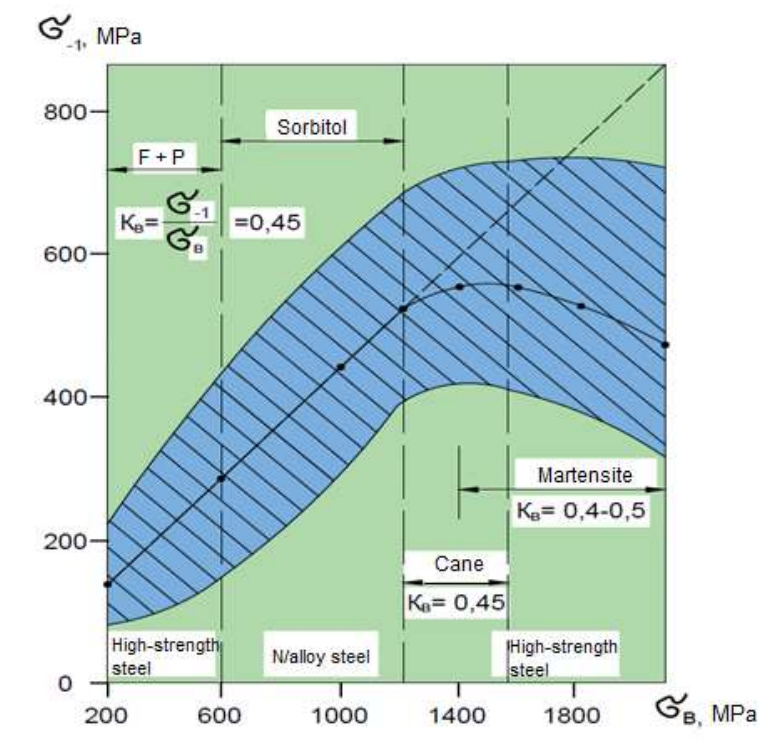

Fig. 4. Influence of the type of reinforcing steel structure on its endurance limit $\left(\sigma_{-1}\right.$. $)$ Designation: $\mathrm{K}_{\mathrm{V}}$ - coefficient of endurance; $\sigma_{B}$ - tensile strength; $\sigma_{-1}$ - limit of fatigue strength (endurance); $\mathrm{F}$ - ferrite; $\mathrm{P}$ - perlite

At surface hardening two mechanisms of increase of cyclic durability are used, in particular there is an increase in resistance to deformations of surface layers of metal and there are residual compressive stresses interfering with emergence and development of fatigue cracks. Combined with external stresses, compressive stresses reduce the level of dangerous tensile stresses on the surface.

The efficiency of the application of surface hardening methods increases with increasing stress concentration. The most effective is the combination of different hardening methods (chemical-thermal treatment, HFC hardening) with surface deformation because the latter additionally (by 10...20\%) increases the hardness of the surface layers and the level of residual compressive stresses. It is recommended to use a surfactant that prevents the development of the process of adsorption 
fatigue. It should be noted that most technologies of surface hardening of reinforcement have a positive effect on its wear resistance and cyclic durability.

In the process of heat treatment, reinforcing steel has undergone all stages of austenitic transformation. In particular, as is known, the pearlitic transformation of supercooled austenite is crystallization in nature, its mechanism is diffusion [3, 4]. This follows from the fact that austenite is almost homogeneous in terms of carbon concentration, decomposes with the formation of ferrite (almost pure iron) and cementite with a content of $6.6 \% \mathrm{C}$, ie a mixture of phases with different concentrations of carbon (Fig. 5).

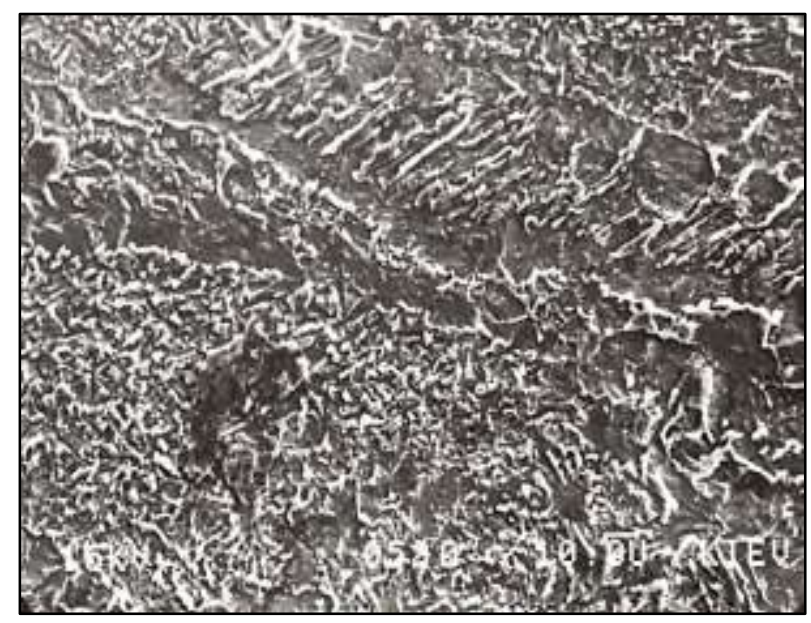

Fig. 5. Structure of perlite and cementite needles $\left(\mathrm{Fe}_{3} \mathrm{C}\right)$ in the decay of austenite reinforcing steel (20ХСНДА) - (x500)

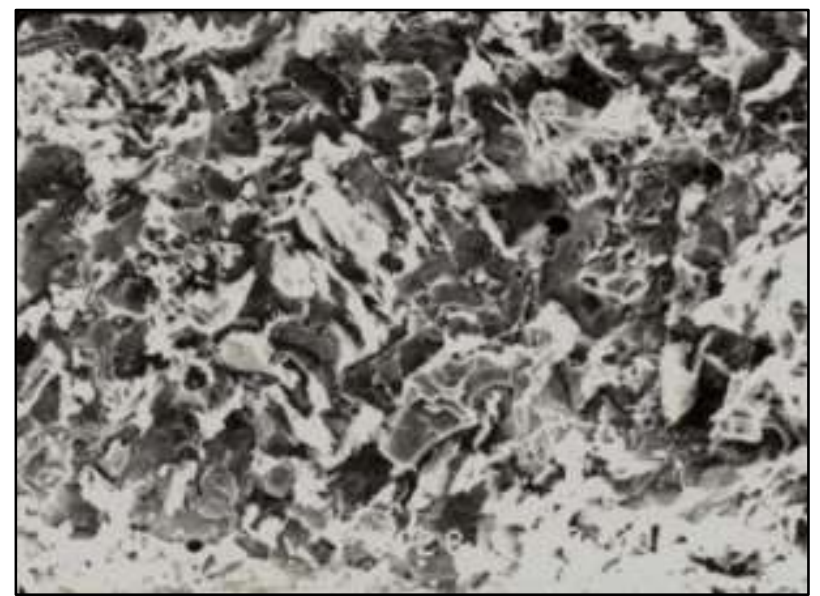

Fig. 6. Microstructure of martensite and residual austenite of reinforcing steel (x600)
The main phase is martensite (Fig. 6).

The growth of the cementite germ is due to the diffusion of carbon from the adjacent volumes of austenite. This eventually leads to its transformation into ferrite. At the same time there is an increase in the thickness of the plates of ferrite and cementite (see Fig. 4). Thus, on the surface of the formed pearlite grain there are also germs of cementite with a different orientation. This process continues until the collision of individual grains and the transformation of all austenite. Moreover, the lower the decay temperature of austenite, the more dispersed is the ferrito-cementite mixture (Fig. 7, 8).

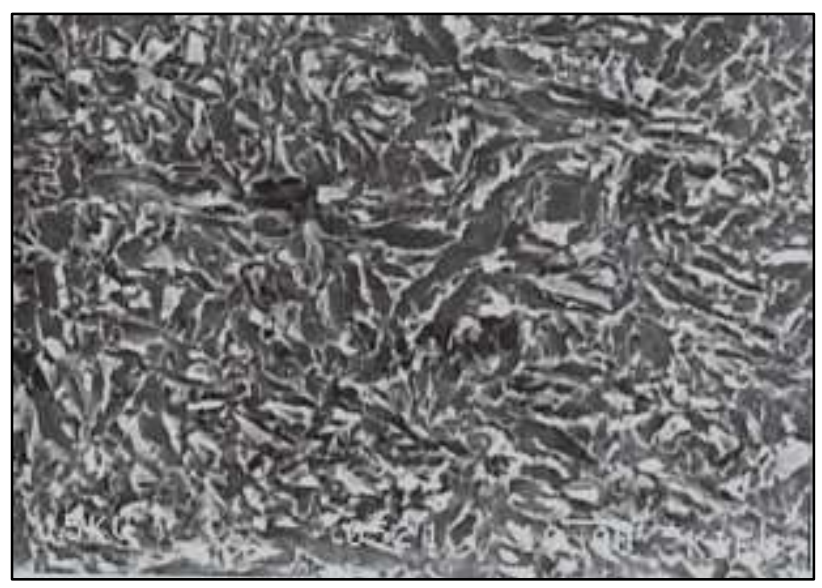

Fig. 7. The effect of temperature on the formation of the structure (fine) sorbitol during the decay of austenite (transformation at $\left.650 \ldots 680^{\circ} \mathrm{C}\right)$

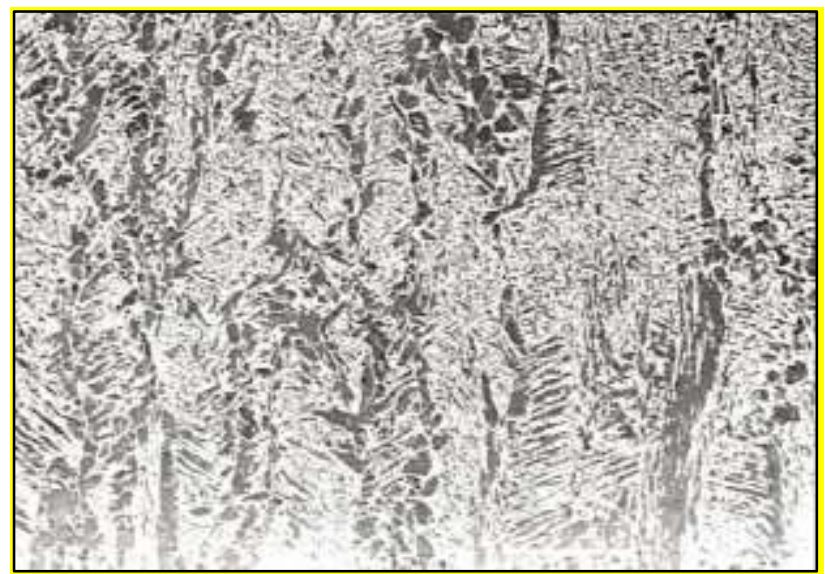

Fig. 8. The structure of sorbitol of reinforcing steel 20ХСНДА during the decay of austenite (conversion temperature $-400 \ldots 599^{\circ} \mathrm{C}$ ) (x1500)

Transfer of Innovative Technologies Vol.4, No.2 (2021), 28-40 
It should be noted that the degree of dispersion is usually characterized between the lamellar distance $\Delta$, under which take the average sum of the thicknesses of the plates of ferrite and cementite. It should be noted that the thickness of carbide plates is determined by the mobility of carbon atoms, which depends on temperature. It is established [2...4] that with a large supercooling (up to temperatures of $500 \ldots 550^{\circ} \mathrm{C}$ ) a more dispersion mixture called cane is formed (Fig. 9).

At magnifications of the order of 1,500 times or more, this is clearly visible on the electron microscope. The authors of this work found that the distance between the plate in perlite is $0.5 \ldots 1.2 \mu \mathrm{m}$, sorbitol $\approx 0.35 \mu \mathrm{m}$ and trostite $\approx 0.2 \mu \mathrm{m}$ (see Fig. 9).

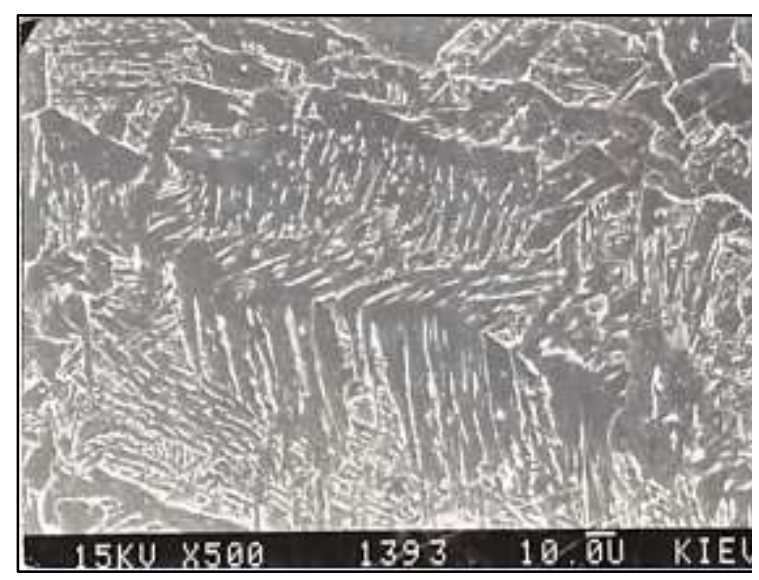

Fig. 9. Microstructure of the rebar of reinforcing steel $20 \Gamma \mathrm{C}(\mathrm{x} 1600)$

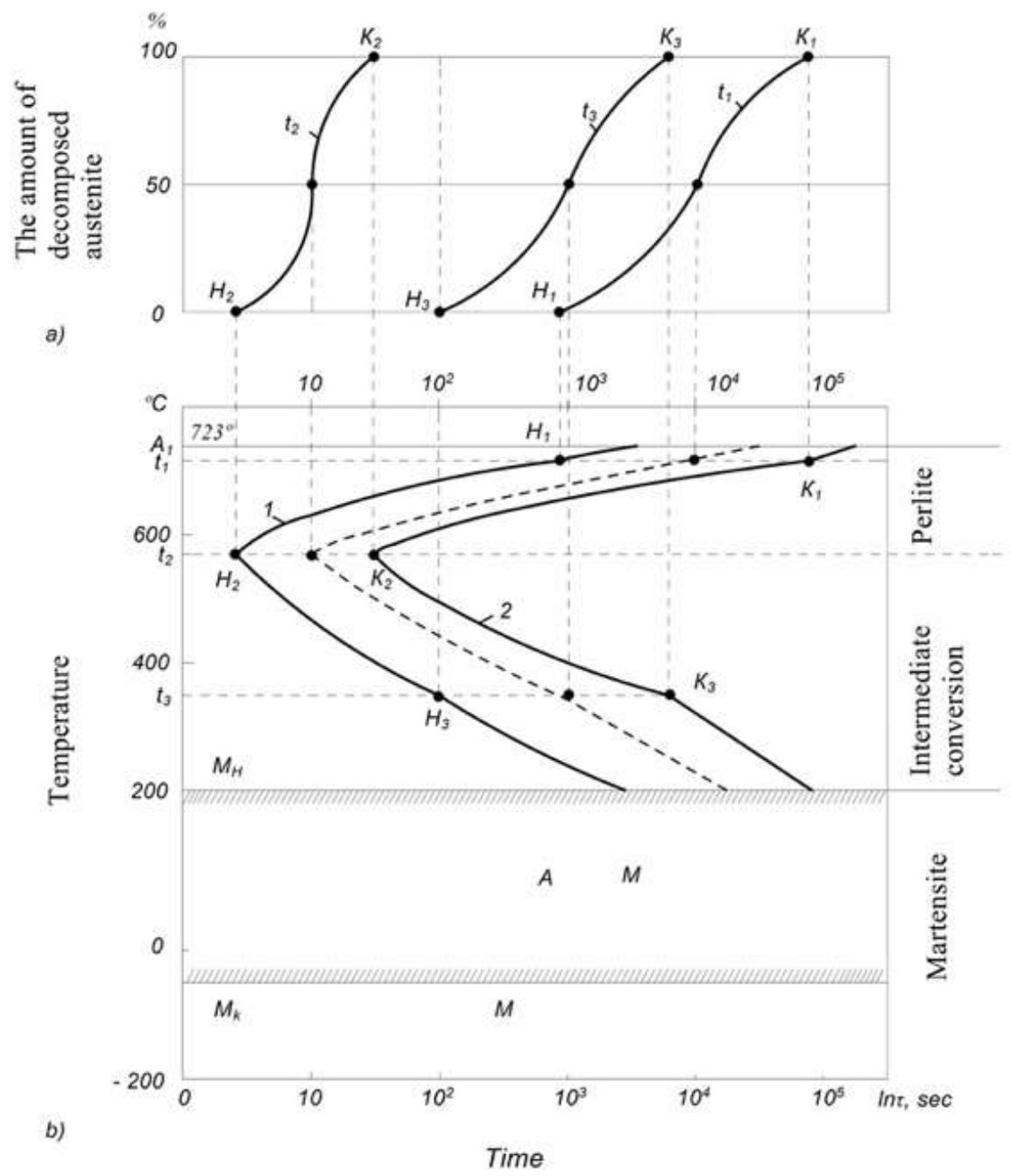

Fig. 10. Construction of the diagram of isothermal transformation of supercooled austenite for reinforcing steel 20ГC. Notation: a) kinetic curves; b) diagram of isothermal transformation of austenite 
It is known [5, 6] that the intermediate transformation takes place at low cooling temperatures of austenite $400 \ldots 200^{\circ} \mathrm{C}$, when the diffusion of iron atoms is almost impossible, and the diffusion of carbon atoms is relatively easy. Therefore, the diffusion process of ferrite formation becomes impossible, and the formation of iron carbide and its separation from austenite and ferrite can occur [3, 4]. Therefore, the kinetics of the intermediate transformation and the structures formed in this case have features of both diffusion (pearlitic) transformation and nondiffusion (martensitic) transformation.

In general, the mechanism of intermediate transformation is as follows. In the intermediate temperature range, the supercooled austenite undergoes transformation (decay) after some incubation period. Initially, there is a diffusion redistribution of carbon inside the austenite, which leads to the formation of volumes of austenite enriched and depleted of carbon (see Fig. 10). Areas of carbon-depleted austenite undergo a non-diffusion transformation $\gamma \rightarrow \alpha$. In the non-diffusion transformation $\gamma \rightarrow \alpha$, only the lattice type (FCC $\rightarrow$ BCC) changes without changing the location of the carbon
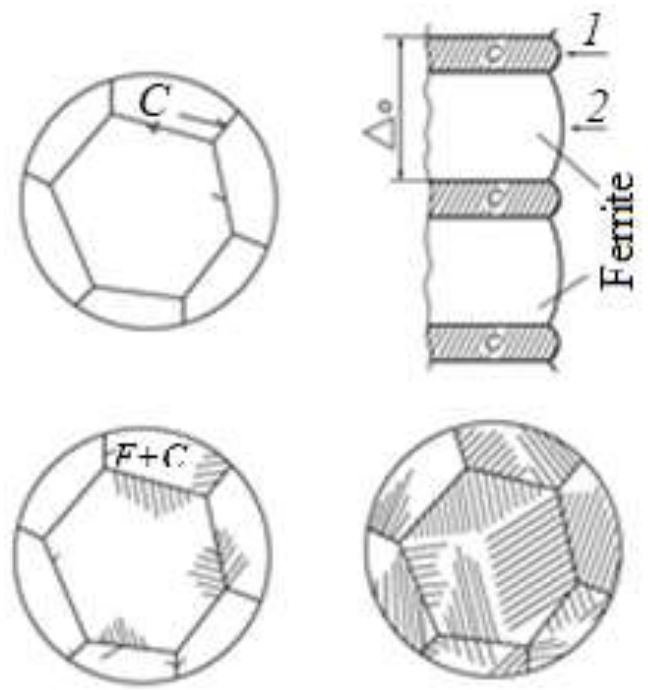

Fig. 11. Schematic representation of the origin and growth of pearlite grain.

Designation: C - cementite; F + C - ferrite plus cementite; 1 - high concentration of carbon $(6.67 \%)$; 2 low carbon concentration $(0.002 \%) ; \Delta_{o}$ - between the plate distance atoms in austenite. Therefore, as a result of such transformation, a supersaturated solid $\alpha$ solution (martensite) is formed, which is an unstable structure and decomposes into a ferritic-cementite mixture at isothermal exposure. Thus, as a result of the intermediate transformation, a structure is formed, which consists of a mixture of $\alpha$-phase and carbide (cementite), which is called bainite (see Fig. 1), and sometimes needle cane. Thus, the intermediate transformation of austenite combines the diffusion redistribution of carbon in austenite with the non-diffusion (martensite) transformation $\gamma \rightarrow \alpha$. It should be noted that in the upper bainite is concentrated mainly the structure of sorbitol similar to the structure of

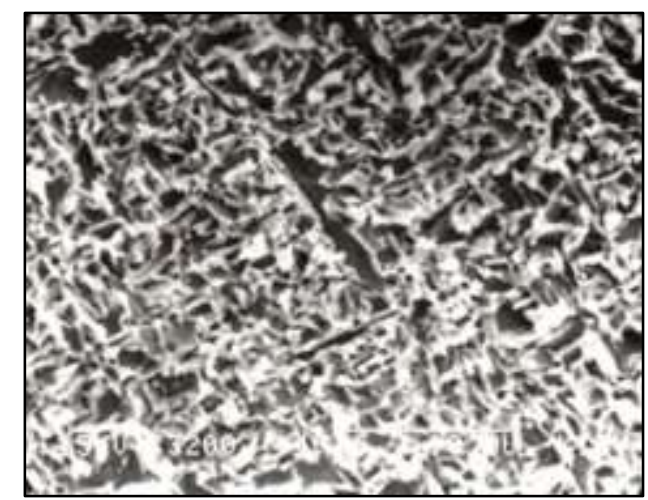

Fig. 12. Microstructure of bainite of reinforcing steel $20 \Gamma \mathrm{C}(\mathrm{x} 1000)$

perlite, and in the lower bainite carbide particles are located inside the plate of the $\alpha$ phase (Fig. 11).

The above data are confirmed by the microstructure of bainite grain (Fig. 12).

\section{REFERENCES}

1. Makhutov N.A., 1981. Deformation criteria of destruction. Moscow, Mashinostroenie, 272 (in Russian).

2. Archakov Yu.I., 1980. Hydrogen corrosion of steel. Moscow: Metallurgy, 192 (in Russian)

3. Atomic mechanism of destruction, 1983, trans., ed. MA Stremel. Moscow: Mir, 660 (in Russian).

4. Kalachev B.A., 1985. Hydrogen brittleness of metals. Moscow: Metallurgy, 216 (in Russian). 
5. Meshkov Yu.Ya., 1985. Physical foundations of the strength of steel structures. Kyiv, Naukova Dumka, 266 (in Russian).

6. Petrov L.N. Sopronyuk N., 1988. Corrosionmechanical destruction of metals and alloys. Kyiv, Naukova Dumka ,488 (in Russian).

7. Makarenko V.D., Mangura A.M., Sizonenko A.V., Litvyak O.L., 2019. Mechanisms of corrosion-carbon corrosion of structural tubular steels for oil and gas application. Modernization and engineering development of resourcesaving technologies in mining and processing of minerals. Collective monograph. Petroshan, Romania: Universitas Publishing, 424, 57-70 (in Ukrainian).

8. Makarenko V., Vynnykov Y., Liashenko A., Petrash O., 2019. Hydrate Formations Modeling for the Oil and Gas Facilities Reconstruction. Proceedings of the 2nd International Conference on Building Innovations. ICBI Lecture Hydrate Formations Modeling for the Oil and Gas Facilities Reconstruction Notes in Civil Engineering, Vol.73, Springer, Cham. 651-658 (in Ukrainian).

9. Boyko A.V., Makarenko V.D., Maximov S.Yu., 2021. On some mechanical characteristics of structural steels of cooling systems of long operation. Problems of durability, No.2 (470), 77-81 (in Russian).

10. Makarenko, V.D., \& Morgun, I.D., 1991. Special features of the effect of barium on the mechanical properties of metal deposited in welding with calcium fluoride electrodes. Welding International, 5(9), 726-728 (in Ukrainian).

11. Pokhodnya I.K., Ponomarev V.E., Milichenko S.S., Skorina N.V., Makarenko V.D., Marchenko A.E., Gorpenyuk V.N., 1987. Effects of type of binder and its composition on the welding and properties of electrodes with basic coatings. Welding International, 1(2), 116-118 (in Russian).

12. Sukach M.K., 2021. The Staple-ShapePlate Springs Engineering Calculation Method. Science and Technique. 20 (3), 268-274, https://doi.org/10.21122/2227-1031-2021-20-3 (in Russian).

13. Pushkarova K., Sukhanevych M., Bondar K. (2015). The principles of composite construction penetrability waterproofing mortars with increased service life. Underwater Technologies Iss.02, 46.

14. Mishchuk D., 2015. Research of the manipulator dynamics installed on an elastic basis. Underwater Technologies, Iss.02, 54.
15. Horbatenko Y., 2020. The production of the splash phenomenon, as a way of dissipating the energy of a gravitational wave. Underwater Technologies, Iss.10, 58.

16. Sukach M.K., 2018. The theoretical basis for calculatingthe bracketed leaf springs. Transfer of Innovative Technologies, Vol.1, No.2, 40-50. https://doi.org/10.31493/tit1812.0201 (in Russian).

17. Chernyshev D.O., 2017. Methodological principles of providing the reliability of organizational and technological solutions in projects of biosphere construction buildings. Management of development of complex system, Vol.32, 210-215 (in Ukrainian).

18. Khomutetska T.P., 2015. Ways to ensure the effective operation of water supply companies / TP Khomutetska. Khomutetska. Problems of water supply, drainage and hydraulics: Science and Technology, Iss.25, Kyiv, 273-279 (in Ukrainian.

\section{Исследование взаимосвязи предела прочности и долгосрочной усталости стальночј укрепления железобетонных конструкций}

\section{Денис Чернышев, Юлия Макаренко, Татьяна Хомутеикая, Валерий Макаренко}

Аннотация. Результаты экспериментальных исследований показали сильное влияние диффузионного водорода на статические и циклические параметры трещиностойкости арматурной стали. Было обнаружено, что с увеличением затопления, особенно когда содержание водорода превышает $5 \mathrm{~cm}^{3} / 100$ г, как статическая прочность, так и длительная прочность (усталость) резко снижаются. Причем эти участки раствора водорода в арматурной стали характеризуются вязким характером разрушения, тогда как для сильно обводненной арматуры (от 5 до $12 \mathrm{~cm}^{3} / 100$ г) характерно хрупкое разрушение по механизму микротрещин в закаленной (мартенситной или трооститовой) стали. Анализ полученных экспериментальных результатов позволил определить оптимальное содержание водорода в арматурной стали (3... $5 \mathrm{~cm}^{3} / 100$ г), превышение которого может вызвать снижение трещиностойкости арматуры при длительной эксплуатации, особенно в агрессивных средах.

Предложен механизм влияния водорода на трещиностойкость металла при статическом и 
знакопеременном нагружении, который заключается в диффузии и перемещении дислокаций водорода в структуре армирующего стержня, что в результате вызывает сильное заливание стали и увеличения ее хрупкости. Установлено, что углеродные и низколегированные стали, характеризующиеся ферритно-перлитной и сорбитовой структурой, обеспечивают высокую стойкость, особенно к длительной усталости, и переходу на стали со структурой мартенсита или отпуска (переходная структура бейнита). Структура бейнита резко снижает прочность арматурной стали, что делает невозможным использование ее при изготовлении арматуры для железобетонных конструкций, рассчитанных на длительную эксплуатацию (более 50... 60 лет). Таким образом, полученная схема может быть рекомендована проектировщикам железобетонных конструкций гидротехнического назначения, так как значительно облегчает разумный выбор арматуры при разработке железобетонных конструкций ответственного и длительного использования.

Ключевые слова: трещиностойкость, затопление, усталость, цикличность, арматура. 